\title{
Recent patents in plant biotechnology
}

\begin{tabular}{|c|c|c|c|c|c|}
\hline Patent \# & Subject & Assignee & Inventor(s) & $\begin{array}{l}\text { Priority } \\
\text { application } \\
\text { date }\end{array}$ & $\begin{array}{l}\text { Publication } \\
\text { date }\end{array}$ \\
\hline WO 200320016 & $\begin{array}{l}\text { A substantially purified promoter of soybean (Glycine max) } \\
\text { capable of transcribing heterologous nucleic acid sequences } \\
\text { in seeds; useful for transforming plants. }\end{array}$ & $\begin{array}{l}\text { Monsanto } \\
\text { Technology } \\
\text { (St. Louis, } \\
\text { MO, USA) }\end{array}$ & $\begin{array}{l}\text { Dubois } P \text {, } \\
\text { Wang } Q\end{array}$ & 9/5/2001 & 3/13/2003 \\
\hline WO 200313226 & $\begin{array}{l}\text { A method for producing a herbicide-resistant or tolerant plant } \\
\text { (particularly to herbicides of the phosphonomethylglycine } \\
\text { family, such as glyphosate) by introducing into a plant cell a } \\
\text { recombinatorial oligonucleobase to produce a mutant 5-enol } \\
\text { pyruvylshikimate-3-phosphate synthase (EPSPS) gene. }\end{array}$ & $\begin{array}{l}\text { Cibus Genetics } \\
\text { (San Diego, CA, } \\
\text { USA) }\end{array}$ & $\begin{array}{l}\text { Avissar P, } \\
\text { Beetham P, } \\
\text { Gocal G, } \\
\text { Knuth M, } \\
\text { Walker K }\end{array}$ & 8/9/2001 & 2/20/2003 \\
\hline WO 200300866 & $\begin{array}{l}\text { A biologically pure culture of Trichoderma asperellum CECT } \\
\text { 20417, useful for the control of the plant pathogens Fusarium } \\
\text { and Rhizoctonia in plant-growth substrates. }\end{array}$ & $\begin{array}{l}\text { University of } \\
\text { Barcelona } \\
\text { (Spain) }\end{array}$ & $\begin{array}{l}\text { Cotxarrera } \\
\text { Vilaplana ML, } \\
\text { Trillas Gay MI }\end{array}$ & 6/26/2001 & $1 / 3 / 2003$ \\
\hline WO 200281622 & $\begin{array}{l}\text { A method for enhancing the growth, fruit yield and flowering rate } \\
\text { of a plant by expressing the inorganic carbon transporter } \\
\text { polypeptide, ictB. }\end{array}$ & $\begin{array}{l}\text { Yissum Research } \\
\text { Development Co. } \\
\text { (Jerusalem, } \\
\text { Israel) }\end{array}$ & $\begin{array}{l}\text { Kaplan A, } \\
\text { Lieman-Hurwitz J, } \\
\text { Mittler R, } \\
\text { Rachmilevitch S, } \\
\text { Schatz D }\end{array}$ & 4/9/2001 & $10 / 17 / 2002$ \\
\hline WO 200281647 & $\begin{array}{l}\text { A genetically modified plant cell comprising a heterologous } \\
\text { nucleotide sequence encoding a bioluminescent polypeptide } \\
\text { that is expressed in an amount sufficient to produce visible } \\
\text { light; useful as research tool and to produce transgenic } \\
\text { plants with ornamental value. }\end{array}$ & $\begin{array}{l}\text { Scripps Research } \\
\text { Institute } \\
\text { (La Jolla, CA, } \\
\text { USA) }\end{array}$ & $\begin{array}{l}\text { Kay SA, } \\
\text { Kuhlmann T, } \\
\text { Lerner RA }\end{array}$ & $4 / 6 / 2001$ & $10 / 17 / 2002$ \\
\hline WO 200278427 & $\begin{array}{l}\text { A plant that is, or is capable of being, male-sterile by virtue } \\
\text { of modulation of the expression of an extrasporogenous cell } \\
\text { (ESP) gene, or of the activity of the encoded ESP protein; useful } \\
\text { for plant breeding programs, food processing and agriculture. }\end{array}$ & $\begin{array}{l}\text { Isis Innovation } \\
\text { (Oxford, UK) }\end{array}$ & $\begin{array}{l}\text { Canales } \mathrm{C} \text {, } \\
\text { Dickinson } \mathrm{H} \text {, } \\
\text { Scott } \mathrm{R}\end{array}$ & 3/30/2001 & $10 / 10 / 2002$ \\
\hline US 6441272 & $\begin{array}{l}\text { A plant with reduced and/or altered lignin content compared to } \\
\text { a comparable wild type; useful as a feedstock by improving the } \\
\text { digestibility of forage crops, and also in improving timber- } \\
\text { extraction processes by reducing the chemical and energy } \\
\text { demands, leading to decreased environmental pollution. }\end{array}$ & $\begin{array}{l}\text { University of } \\
\text { Georgia Research } \\
\text { Foundation } \\
\text { (Athens, GA, USA) }\end{array}$ & Ye Z & 12/2/1998 & 8/27/2002 \\
\hline WO 200258459 & $\begin{array}{l}\text { A tree cell transformed by an altered acetohydroxyacid } \\
\text { synthase (AHAS) nucleic acid. The gene's expression results } \\
\text { in increased resistance to an imidazolinone herbicide, } \\
\text { particularly when employed using spray-over techniques to } \\
\text { control weeds within the tree's vicinity. }\end{array}$ & $\begin{array}{l}\text { Karnosky DF; } \\
\text { Podila GK; } \\
\text { Xiang B; } \\
\text { BASF Plant } \\
\text { Science (Ludwig- } \\
\text { shafen, Germany) }\end{array}$ & $\begin{array}{l}\text { Karnosky DF, } \\
\text { Podila GK, } \\
\text { Xiang B }\end{array}$ & $1 / 25 / 2001$ & $8 / 1 / 2002$ \\
\hline US 6410826 & $\begin{array}{l}\text { Reducing lignification in vascular plants (including woody } \\
\text { plants, leguminous plants and forage grass) comprising } \\
\text { introducing an exogenous nucleic acid molecule encoding } \\
\text { an AGL8-like gene product. }\end{array}$ & $\begin{array}{l}\text { Regents of the } \\
\text { University of } \\
\text { California } \\
\text { (Oakland, CA, USA) }\end{array}$ & $\begin{array}{l}\text { Ferrandiz C, } \\
\text { Liljegren S, } \\
\text { Yanofsky MF }\end{array}$ & 6/25/1998 & 6/25/2002 \\
\hline WO 200231113 & $\begin{array}{l}\text { A method for regenerating genetically modified pine plants } \\
\text { (Pinus spp.) selected from Southern yellow pines and its hybrids, } \\
\text { involving the selection of transgenic embryogenic pine cells in } \\
\text { the presence of an agent that regulates differentiation of } \\
\text { embryos from embryogenic cells. }\end{array}$ & $\begin{array}{l}\text { Westvaco } \\
\text { (Stamford, CT, } \\
\text { USA); Connett- } \\
\text { Porceddu MB; } \\
\text { Gulledge JE }\end{array}$ & $\begin{array}{l}\text { Connett- } \\
\text { Porceddu MB, } \\
\text { Gulledge JE }\end{array}$ & $6 / 12 / 2001$ & 4/18/2002 \\
\hline
\end{tabular}

Source: Derwent Information, Alexandria, VA. The status of each application is slightly different from country to country. For further details, contact Derwent Information, 1725 Duke Street, Suite 250, Alexandria, Va 22314. Tel: 1 (800) DERWENT (info@derwent.com). 